New Data on Digenean Parasites of Rusty Blenny, Parablennius sanguinolentus (Pallas, 1814) in the Black Sea

\author{
Türkay ÖZTÜRK* and Arzu G̈̈VEN \\ Sinop University, Faculty of Fisheries and Aquatic Sciences, Sinop, Turkey
}

\begin{abstract}
Rusty blenny, Parablennius sanguinolentus (Blenniidae) caught in Sinop coasts of the Black Sea between May to June 2016 was investigated for digenean parasites. A total of nine digenean species including adults of Peracreadium genu Nicoll, 1909, Phyllodistomum acceptum Looss, 1909, Magnibursatus blennii (Paggi and Orecchia, 1975), Monorchis monorchis (Stossich,1890) Monticelli, 1893, and metacercaria of Galactosomum lacteum (Jägerskiöld, 1896), Bucephalus marinus Vlasenko, 1931, Rhipidocotyle sp., Prosorhynchoides sp. and Opecoelidae gen. sp. were identified. The infection prevalence (\%), mean intensity levels and photomicrographs of identified parasites are presented in tables and figures, respectively. Overall infection prevalence $(\%)$ and mean intensity values were $100 \%$ and $506.40 \pm 120.78$ respectively. This investigation is the first on the digenean parasites of $P$. sanguinolentis in Turkish Black Sea coasts. Bucephalus marinus was the core species. Peracreadium genu and Magnibursatus blennii are new parasite record for Turkey.
\end{abstract}

Keywords: Blenniidae, Parablennius sanguinolentus, digenean, parasites, Black Sea

\title{
Karadeniz'deki Horozbina Balığının, Parablennius sanguinolentus (Pallas, 1814) Digenea Parazitleri İle İlgili Yeni Veriler
}

\section{Öz}

Karadeniz'in Sinop kıyılarından Mayıs-Haziran 2016 tarihleri arasında yakalanan horozbina balığ 1 , Parablennius sanguinolentus, digenea parazitleri yönünden incelenmiştir. Ergin Peracreadium genu Nicoll, 1909, Phyllodistomum acceptum Looss, 1909, Magnibursatus blennii (Paggi and Orecchia, 1975), Monorchis monorchis (Stossich,1890) Monticelli, 1893 ve metaserker Galactosomum lacteum (Jägerskiöld, 1896), Bucephalus marinus Vlasenko, 1931, Rhipidocotyle sp., Prosorhynchoides sp. ve Opecoelidae gen. sp. olmak üzere toplam 9 digenea türü tanımlanmıştır. Tanımlanan parazitlerin fotomikrografları, enfeksiyon oranı (\%) ve enfekte balık başına ortalama parazit sayıları tablo ve şekiller ile sunuldu. Toplam enfeksiyon oranı ve enfekte balık başına ortalama parazit sayısı değerleri sırasıyla \%100 ve $506.40 \pm 120.78$ olarak hesaplandı. Bu araştırma, Türkiye'nin Karadeniz kıyılarındaki $P$. sanguinolentis balığının digenea parazitleri üzerine yapılan ilk araştırmadır. Bucephalus marinus ana türdü. Peracreadium genu ve Magnibursatus blennii türleri Türkiye parazit faunası için yeni kayıttırlar.

Anahtar Kelimeler: Blennidae, Parablennius sanguinolentus, digenea, parazit, Karadeniz

\footnotetext{
${ }^{*}$ Corresponding Author: ORCID ID: orcid.org/0000-00001-5568-3214

e-mail: turkay.ozturk@gmail.com
}

Received: 22.11.2019

Accepted: 24.12.2019 


\section{Introduction}

The class Trematoda is the largest group of Platyhelminths and includes two subclasses: Aspidogastrea and Digenea [1]. Digeneans, also called digenetic trematodes or flukes, comprises more than 18000 species that are obligatory parasitic in both invertebrate and vertebrate organisms [2]. Digeneans are permanent parasites in most marine fishes, and in many freshwater fishes, amphibians, reptiles, mammals and birds. The life cycle of digeneans is quite complex and characterized by succession of several stages known as the egg, miracidium, sporocyst, redia, cercariae, metacercaria and adult. Moreover, they use at least two hosts as intermediate and final hosts besides free-living stages in their complex life cycles. Digeneans are important fish parasites and fish serve as both intermediate and final hosts. Adults usually occur in the intestine, stomach or mouth, or occasionally internal organs, while larval forms occur in almost any tissue of fishes [3].

The rusty blenny or Black Sea blenny, Parablennius sanguinolentus, is a member of Blenniidae and distributed in the eastern Atlantic including the Mediterranean, and the Black Seas [4]. Despite its widespread distribution, studies on the parasites of this fish is very limited $[5,6,7,8,9]$. So far, 9 digenean species have been reported in $P$. sanguinolentis from the Black Sea $[8 ; 10,11]$, but there were no data on the digenean parasite fauna of the rusty blenny in the Turkish coasts of the Black Sea. This paper is the first report on the digenean parasites of rusty blenny, $P$. sanguinolentus from Sinop coasts of the Black Sea.

\section{Material and Methods}

Fish specimens were caught from Sinop coasts of Black Sea. A total of 5 fish specimens were collected in between May to June 2016. Parasitological investigation was conducted at parasitology laboratory in the Faculty of Fisheries and Aquatic Sciences in Sinop. Dissections were performed under a dissecting microscope using standart parasitological techniques. The examination included skin, muscles, internal organs, brain, eyes, gills, body cavity, and visceral organs (heart, stomach, intestine, liver, swim bladder and gonads). Isolated parasite species and their site of infection in the host were recorded. The prevalence (the percentage of infected fish), mean intensity (the average number of parasites in the total number of infected fish) were calculated according to Bush et al. [12]. The standard error (SE) for mean intensity is given. 


\section{Results and Discussion}

A total of 9 digenean parasite species belonging to Bucephalidae, Opecoelidae, Derogenidae, Gorgoderidae, Monorchidae and Heterophyiidae were detected. These are; Bucephalus marinus Vlasenko, 1931, Rhipidocotyle sp., Prosorhynchoides sp., Peracreadium genu Nicoll, 1909, and Opecoelidae gen. sp., Phyllodistomum acceptum Looss, 1909, Monorchis monorchis (Stossich,1890) Monticelli, 1893, Magnibursatus blennii
(Paggi \& Orecchia, 1975), and Galactosomum lacteum (Jagerskiöld, 1896). Infection indices such as the infection prevalence $(\%)$, mean intensity values and microhabitat preferences of each parasite species are presented in Table 1. Overall infection prevalence $(\%)$ and mean intensity (MI) values were $100 \%$ and $506.40 \pm$ 120.78 parasites per infected fish, respectively (Table 1). Bucephalus marinus was the core species.

Table 1. Digenean parasite species found in the rusty blenny, Parablennius sanguinolentus

\begin{tabular}{|l|l|c|c|}
\hline Digenean species & Microhabitat & P (\%) & Mean Intensity \pm S.E \\
\hline Bucephalus marinum met. & gills, heart & 100 & $504.6 \pm 121.19$ \\
\hline Rhipidocotyle sp. met. & heart & 100 & $25.60 \pm 18.83$ \\
\hline Prosorhynchus sp. met. & heart & 60 & $26.00 \pm 17.89$ \\
\hline Opecoelidae gen. sp. met. & gills & 60 & $1.70 \pm 0.67$ \\
\hline Peracreadium genu & Intestine & 40 & $7.00 \pm 4.00$ \\
\hline Phyllodistomum acceptum & kidney, urinary bladder & 40 & $11.50 \pm 10.5$ \\
\hline Monorchis monorchis & intestine & 20 & $8.00 \pm 0.00$ \\
\hline Magnibursatus blennii & gills & 40 & $1.00 \pm 0.00$ \\
\hline Galactosomum lacteum met. & kidney & 20 & $4.00 \pm 0.00$ \\
\hline
\end{tabular}

P: prevalence (\%); met.: metacercaria; S.E.: Stardard Error

\section{Family Bucephalidae Poche, 1907}

This family is commonly found in marine, brackish and freshwater teleost fish and is frequently reported [13]. The members of this family lack suckers, having instead a muscular organ called a "rhynchus" at the front end which they use to attach to their hosts. Sucker-like rhynchus is characterised by having a with a hood bearing usually seven tentacles. The morphological features of Rhynchus are important in defining the genus level of the family. The family Bucephalidae includes 36 genera. 
In the present study, three digenean species recorded as encysted metacercariae belonging to Bucephalidae were identified (Table 1 and Figure 1) and these were
Bucephalus marinus (Figure 1A), Rhipidocotyle sp. (Figure 1B) and Prosorhynchoides sp. (Figure 1C).

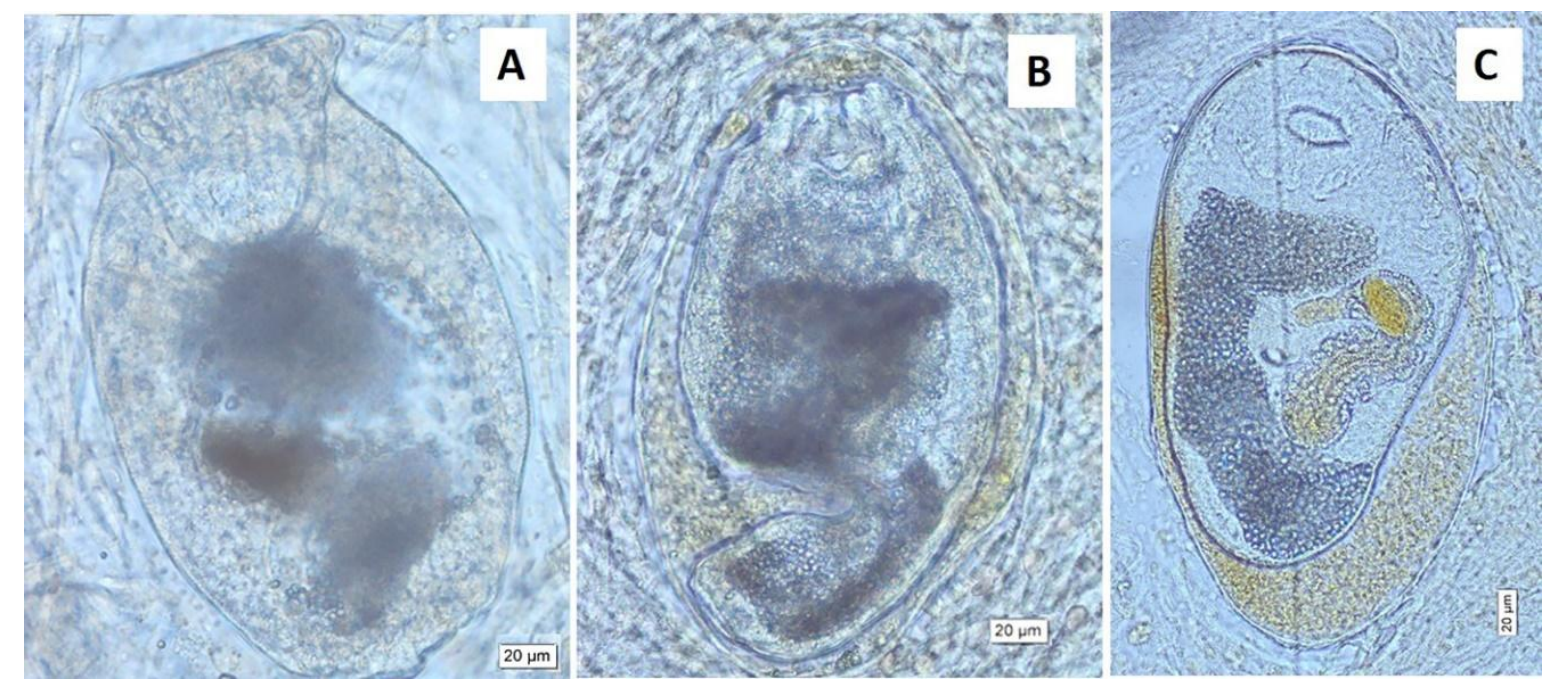

Figure 1. Metacercariae belonging to Bucephalidae. A. excysted metacercaria of Bucephalus marinus, $\boldsymbol{B}$. encysted metacercaria of Rhipidocotyle sp., $\boldsymbol{C}$. encysted metacercaria of Prosorhynchoides sp.

\section{Bucephalus marinus Vlasenko, 1931} (Figure 1A)

Syns: Bucephalus marinum

Infection values: The data are presented in Table 1.

This digenean species have previously been reported from $P$. sanguinolentus in the Black Sea $[8,10$, 11]. Moreover, it has been previously reported from another blenniid species, $P$. tentacularis, in Sinop coasts of the Black Sea [14]. But this is its first report from $P$. sanguinolentis in the Turkish coasts.
Rhipidocotyle sp. (Figure 1B)

\section{Syns: Gasterostomum}

Infection values: The data are presented in Table 1.

The genus Rhipidocotyle is represented by a very large number of species parasitic in marine fishes but only a few from freshwater fishes. So far, two species of this genus, Rhipidocotyle illense and $R$. genovi has been reported in the Black Sea $[11,15]$. The encysted metacercariae of $R$. genovi have been reported in the musculature and fins of blenniid fishes, while its adults in the intestine of Gaidropsarus mediterraneus 
[15]. Although we couldn't identify at the species level, the encysted metacercariae of Rhipidocotyle sp., we have determined in P. sanguinolentis. But we have found the encysted metacercariae in the heart, not in the muscles and fins of the fish.

Prosorhynchoides sp. (Figure 1C)

Syns. Bucephalopsis Diesing, 1855; Neobucephalopsis Dayal, 1948; Bucephaloides Hopkins, 1954

Infection values: The data are presented in Table 1.

Adult members of genus Prosorhynchoides, infect the intestine of freshwater and marine fishes. In the Black Sea fishes, mature worms of only two Prosorhynchoides species have so far been recorded Prosorhynchoides [= Bucephalopsis] gracilescens in Sarda sarda, Lophius piscatorius [11] and $P$. arcuatus in Sarda sarda and in Pomatomus saltatrix [16]. Juvenile stages of $P$. gracilescens have been reported from Belone belone euxini, Merlangius merlangus euxini in the Black Sea [11]. The metacercariae of Prosorhynchoides sp. has not previously been reported in $P$. sanguinolentis, this is the first report from this fish in the Black Sea.

\section{Family Opecoelidae Ozaki, 1925}

The family Opecoelidae is the largest digenean family including the highest number of genera and species among trematodes. To date, belonging to this family more than 90 genera and nearly 900 species have been reported in almost exclusively marine and freshwater teleost fish [17].

In this study, Opecoelidae was represented with 2 species, 1 adult (Peracreadium genu) and 1 metacercariae stage (Opecoelidae gen. sp. met.) (Table 1 and Figure 2). The presence of Opecoelidae gen. sp. met. has been previously reported in $P$. sanguinolentis from Black Sea by Lushchina [10] and Gaevskaya and Kornychuk [11]. 

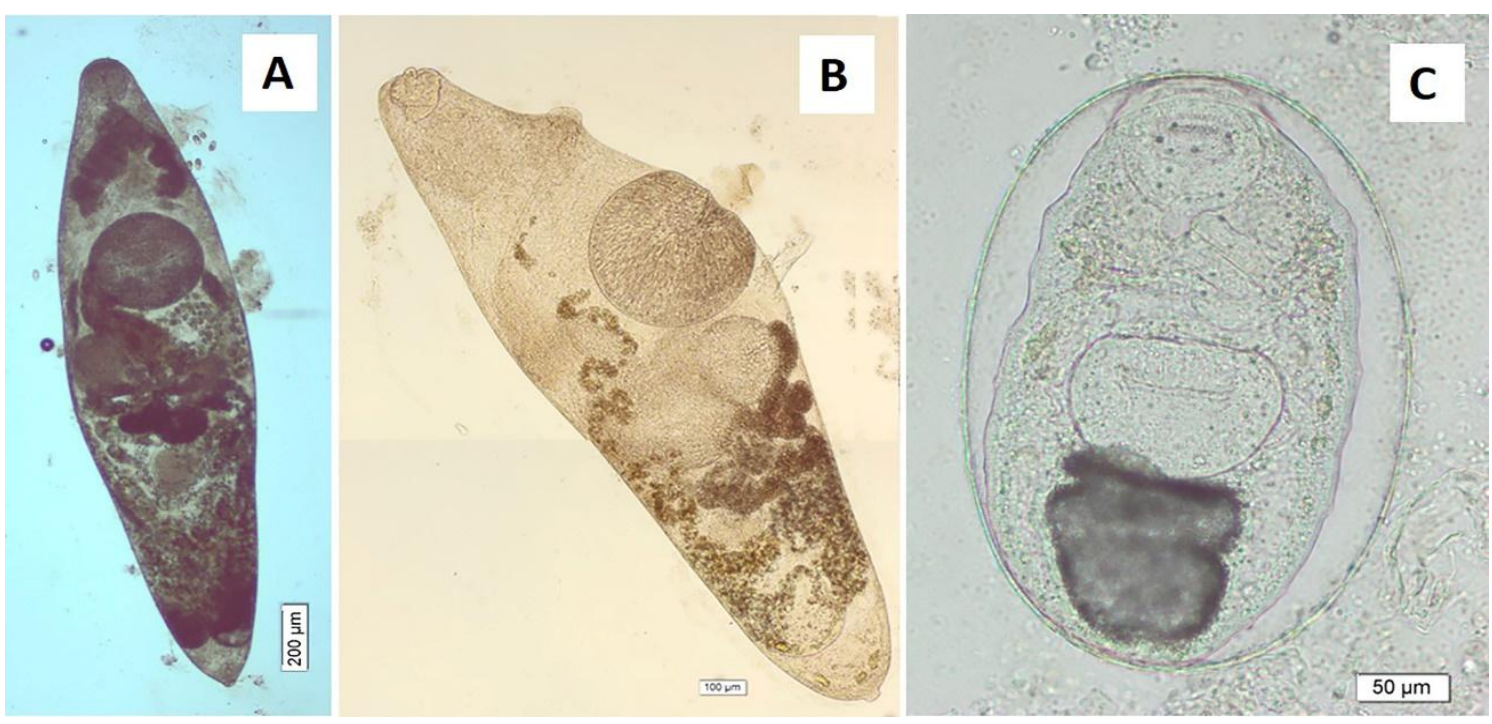

Figure 2. Species of Opecoelidae determined in this study (original). A. Peracreadium genu (adult, ventral view), B. Peracreadium genu (adult, lateral view), C. metacercaria of Opecoelidae gen. sp.

\section{Peracreadium genu Nicoll, 1909 (Figure} 2A-B),

Syns: Distoma genu, Distomum fasciatum, Allocreadium genu

Infection values: The data are presented in Table 1.

This digenean species have previously been reported from Blennius pholis, Labrus berggylta [18, 19] and from Labrus merula and L. viridis [20]. So far, the only member of the genus Peracreadium, P. gibsoni has been reported in Puntazzo puntazzo from Black Sea by Korniychuk and Gaevskaya [21]. This study is the first report on presence of P. genu in Parablennius sanguinolentis and in the Black Sea.

\section{Family Gorgoderidae Looss, 1899}

The family Gorgoderidae is a specific family of trematodes having different morphological features, especially the non-spinous tegument, simple male terminal genitalia, highly narrow vitellarium and wide uterus [22]. Member of the family is relatively unusual among trematodes in being significantly spread in various aquatic vertebrates such as chondrichthyes, actinopterygii and tetrapods. Infections in teleost fishes are typically in the urinary bladder, whereas those in chondrichthyans are usually in the body cavity; a few species are reported from other sites such as swim bladder, gall bladder and intestine [23, 24]. Within the Gorgoderinae, Phyllodistomum Braun, 1899 is by far the largest genus, 
containing over 110 species [25]. Indeed, according to Cribb et al. [26], Phyllodistomum is one of the two largest genera of trematodes.

Phyllodistomum acceptum Looss, 1901 (Figure 3)

Syns: -

Infection values: The data are presented in Table 1.

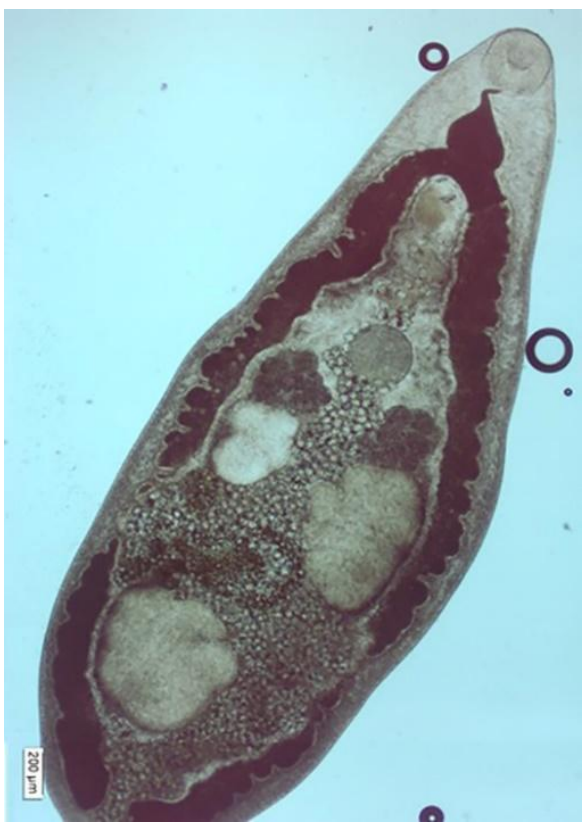

Figure 3. Phyllodistomum acceptum Looss, 1901 (original), (adult, ventral view)

Phyllodistomum species have a wide distribution in both marine and freshwater fish. To date, Phyllodistomum acceptum have been reported from labrid fishes (Symphodus cinereus, S. ocellatus and S. tinca), Serranus scriba and Mullus barbatus in the Black Sea [11]. It has been previously reported from another blenniid species, $P$. tentacularis, in Sinop coasts of the Black Sea [14]. This study is the first report on the presence of $P$. acceptum in $P$. sanguinolentis.

\section{Family Monorchiidae Odhner, 1911}

Members of this family are characterized by the dominion of a spiny tegument, complex terminal genitalia armed with spines, limited vitelline follicles and well- developed uterine coils. They ocur in the gastro-intestinal tract of marine fishes throughout the world. The family includes more than 290 nomimal species in 58 genera [27]. Among members of this family, several genera including Monorchis are characterized by a single testis.

Monorchis monorchis (Stossich, 1890) Monticelli, 1893 (Figure 4),

Syns: Distomum monorchis

Infection values: The data are presented in Table 1.

Monorchis monorchis has been reported from various marine fish belonging to Sparidae and Blenniidae in European waters [5, 28]. Moreover, it has been previously reported from $P$. sanguinolentis from Black Sea [29]. But this is its first report from $P$. sanguinolentis in the Turkish coasts. 


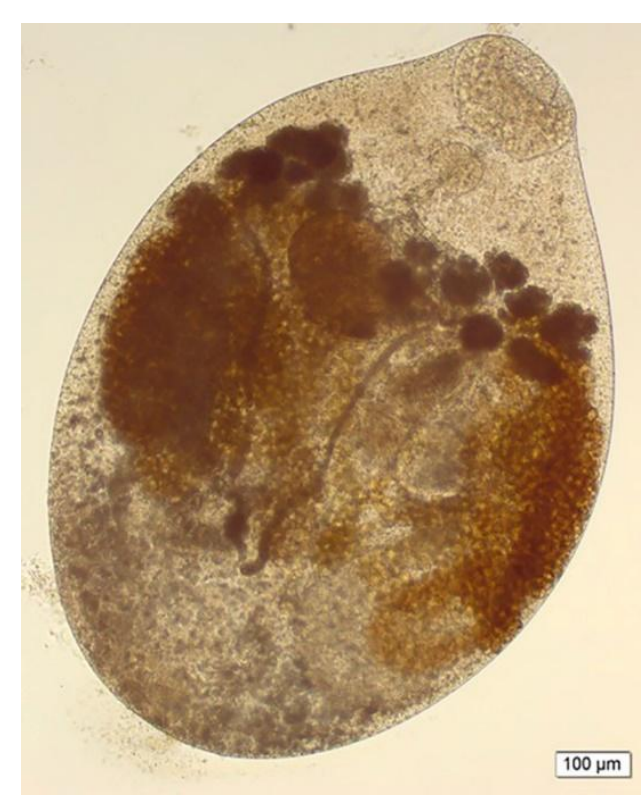

Figure 4. Monorchis monorchis (Stossich, 1890) Monticelli, 1893 (original), (adult, ventral view)

\section{Family Derogenidae Nicoll, 1910}

Members of this family are characterised by an elongated body, an unarmed tegument, well developed oral and ventral suckers, a short oesophagus, two symmetrical or tandem testes, an oval ovary, numerous eggs with or without filaments, and one or two vitelline masses. These digeneans are parasitic in the gut of freshwater and marine teleosts, but are occasionally recorded from reptiles and fresh water shrimps [30]. Mediterranean and Black Sea records of members of this family are few and being mainly limited at one genus, Magnibursatus Naidenova, 1969. To date, the genus Magnibursatus Naidenova (1969) consists of 7 nominal species, most of them being parasites of sparid fishes from Black and Mediterranean Sea fishes [31, 32, 33].

\section{Magnibursatus blennii (Paggi and Orecchia, 1975) (Figure 5A-C)}

Syns: Tyrrhenia blennii Paggi and Orecchia, 1975

Infection values: The data are presented in Table 1.

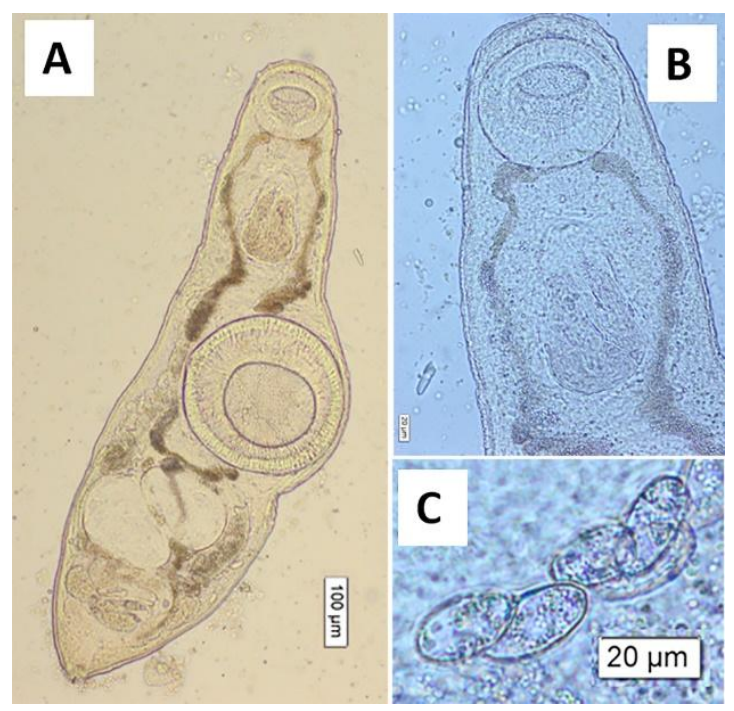

Figure 5A. Magnibursatus blennii (Paggi and Orecchia, 1975) (original). B. anterior end (ventral view), $\boldsymbol{C}$. eggs with filament.

$$
\text { Tyrrhenia is synonymy of }
$$
Magnibursatus and T. blennii is transferred to M. blennii. Magnibursatus (= Tyrrhenia $)$ blennii was identified Parablennius (= Blennius) gattorugine and Parablennius $(=\quad$ Blennius $)$ sanguinolentus from the Gulf of Gaeta, Italy [5]. Later, M. blennii is recorded from Salaria pavo, Paralipophrys trigloides and Parablennius sp. in Corsica coasts [32]. This study is the first report 
on presence of Magnibursatus blennii in $P$. sanguinolentis from the Black Sea.

\section{Family Heterophyidae Leiper, 1909}

Members of this family are characterised by spiny tegument. They are predominantly intestinal parasites of fish eating birds and mammals including humans. Their metacercariae are encysted in diferent organs of fresh-brackishwater and marine fishes. Adult heteropyhid digeneans are parasitic and are important of fish borne zoonoses via consumption of raw or undercooked fish containing metacercaria, the infective larval stages.

\section{Galactosomum lacteum (Jägerskiöld,} 1896) (Figure 6A-C)

Syns: Monostomum lacteum Jägerskiöld, 1896

Infection values: The data are presented in Table 1.

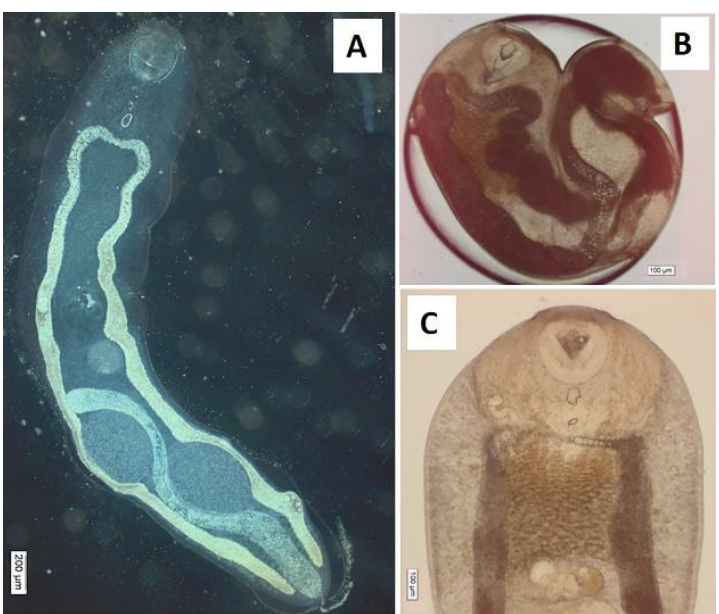

Figure 6A. excysted metacercaria of Galactosomum lacteum, B. encysted metacercaria. C. anterior end (original)
Galactosomum lacteum was first described by Jägerskiöld (1896) as Monostomum lacteum. Until today, it has been reported in at least 29 fish species including blenniid fish from Black Sea [11].

\section{Conclusions}

In conclusion, a total of 9 digenean species were identified from the rusty blenny, Parablennius sanguinolentus in Turkish Black Sea coasts for the first time. The present study on digenean fauna yielded new records: while Peracreadium genu and Magnibursatus blennii are considered as new records for Turkish and Black Sea parasite fauna, $P$. sanguinolentis is a new host record for Phyllodistomum acceptum and Peracreadium genu.

\section{Acknowledgements}

This study is summarized from a part of the project 2150224 supported by The Scientific and Technological Research Council (TÜBİTAK). The authors are grateful for this valuable support.

\section{References}

[1] Toledo R, Fried B, 2017. Trematoda (flukes). Emerging Topics in Life Sciences, 1(6): 651-657. doi:10.1042/etls20170111

[2] Kostadinova A, Pérez-del-Olmo A. 2014. The Systematics of the Trematoda. In: Toledo R, Fried B. (eds) 
Digenetic Trematodes. Advances in Experimental Medicine and Biology, vol 766. Springer, New York, NY]. 766, p. 21 -44. https://doi.org/10.1007/ 978-14939-0915-5_2

[3]. Bunkley-Williams L, Williams EH, 1994. Parasites of Puerto Rican Freshwater Sport Fishes. Puerto Rico Department of Natural and Environmental Resources, San Juan, PR and Department of Marine Sciences, University of Puerto Rico, Mayaguez, PR, 168 p.

[4]. Zander CD, 1996. Ecology of Shallow Coastal The distribution and feeding ecology of small-size fish in the coastal Mediterranean Sea. In: Eleftheriou, A. (ed.), Biology and Waters.

[5] Paggi L, Orecchia P, 1975. Tyrrhenia blennii g.n. sp. n. (Hemiurata: Halipegidae Poche, 1925) parasite of Blennius gattorugine and Blennius sanguinolentus. Parassitologia, 17(1-3): 57-64. (in Italian]

[6] Alas A, Oktener A, Iscimen A, Trilles JP, 2008. New host record, Parablennius sanguinolentus (Teleostei, Perciformes, Blenniidae), for Nerocila bivittata (Crustacea, Isopoda, Cymothoidae). Parasitology Research, 102: 645-646.

[7] Pronkina NV, Belofastova LP, Machkevsky VK, 2009. Occurrence of Nematoda Larvae of the Superfamily Acuarioidea (Spirurata) at the Black Sea Fish. Vestnik zoologii, 43(2): 157-162.

[8] Kvach Y, 2010. The helminth fauna of blenny fishes (Actinopterygii: Blenniidae) of the Gulf of Odessa, Black Sea. Sci. Bull. Uzhgorod Univ. (Ser. Biol.), 28: 129-131.
[9] Özer A. Özkan H, Güneydağ, Yurakhno V, 2015. First Report of Several Myxosporean (Myxozoa) and Monogenean Parasites from Fish Species off Sinop Coasts of the Black Sea. Turkish Journal of Fisheries and Aquatic Sciences 15: 737-744. DOI: 10.4194/1303-2712-v15_3_18

[10] Luschina VG, 1985. To helminth fauna of Blenniidae Family from theBlack Sea. Ekologiya Morya, 20, 43-48 (In Russian)

[11] Gaevskaya AV, Korniychuk YM, 2003. Parasitic organisms as a component of ecosystems of the Black Sea near-shore zone of Crimea. - In: Modern condition of biological diversity in near-shore zone of Crimea (the Black sea sector) / Ed. V.N. Eremeev, A.V. Gaevskaya; NAS Ukraine, Institute of Biology of the Southern Seas. - Sevastopol: EKOSI-Gidrophizika, 2003. - P. $425-490$

[12] Bush AO, Lafferty KD, Lotz JM, Shostak AW, 1997. Parasitology meets ecology on its own terms: Margolis et al. revisited. Journal of Parasitology, 84: 575-583.

[13] Overstreet RM, Curran SS, 2002. Superfamily Bucephaloidea Poche, 1907. In: Gibson DI, Jones A, Bray RA (eds) Keys to the Trematoda, vol 1. Wallingford, CAB International and the Natural History Museum, London, pp 67-110.

[14] Korniychuk YM, Özer A, Güneydağ S, Özkan H, 2016. New data on Digenean parasites of fishes in Sinop region of the Black Sea. Contemporary problems of 
theoretical and marine parasitology: collection of scientific papers, Publisher: Bondarenko Publishing, Editors: K.V. Galaktionov, A.V. Gaevskaya, pp.143-144

[15] Dimitrov G, Kostadinova A, Gibson DI, 1996. Rhipidocotyle genovi n. sp. (Digenea: Bucephalidae) from the intestine of Gaidropsarus mediterraneus (L.) (Gadiformes: Gadidae) from the Black Sea. Systematic Parasitology 33: 209-216.

[16] Dimitrov GI, 1989. Investigations of the helminths of fishes of the Bulgarian Black Sea coast. Autoreferat na Disertacija. Sofia: Bulgarian Academy of Sciences, 35 pp. (In Bulgarian).

[17] Bray RA, Cribb TH,, Littlewood DTJ, Waeschenbach A, 2016. The molecular phylogeny of the digenean family Opecoelidae Ozaki, 1925 and the value of morphological characters, with the erection of a new subfamily. Folia Parasitologica, 63 : 013 doi: 10.14411/fp.2016.013

[18] Dawes B, 1968. The Trematoda: with specieal reference to British and Other European Forms. Cambridge University Press, London, $644 \mathrm{p}$.

[19] Nicoll W, 1914. The trematode parasites of fishes from English Channel. Journal of the Marine Biological Association of United Kingdom, 10: 466505

[20] Abdalah LGB, Elbohli S, Maamouri F, 2010. Digenean diversity in labrid fish from the Bay of Bizerte in Tunisia. Journal of Helminthology, 84(1): 27-33. doi:10.1017/S0022149X09990022
[21] Korniychuk JM, Gaevskaya AV, 2001. Peracreadium gibsoni sp. nov. (Trematoda: Opecoelidae) - a new trematode species from the Black Sea fishes. Ekologiya Morya, 56, pp.27-30. (In Russian, with English Summary).

[22] Campbell RA, 2008. Family Gorgoderidae Looss, 1899. In: Bray R.A., Gibson, D.I. \& Jones, A. (Eds.), Keys to the Trematoda. Vol. 3. CABI Publishing and the Natural History Museum, Wallingford, pp. 191-213.

[23] Bashirullah AKM, Islam MA, 1970. A new phyllodistome from the swimbladder of siluroid fish (Trematoda: Gorgoderidae). Pakistan Journal of Zoology, 2: 25-27.

[24] Cutmore SC, Miller TL, Curran SS, Bennett MB, Cribb TH, 2013. Phylogenetic relationships of the Gorgoderidae (Platyhelminthes: Trematoda), including the proposal of a new subfamily (Degeneriinae $n$. subfam.). Parasitology Research, 112, 3063-3074. http://dx.doi.org/10.1007/s00436-0133481-5

[25] Kudinova MA, 1994. On the revision of system of the trematode genus Phyllodistomum Braun, 1899 (Gorgoderidae). In: Shulman, S.S. (Ed.), Ecological Parasitology. Kaulian Research Center RAS, Petrozavodsk, pp. 96-112.

[26] Cribb TH, Chisholm LA, Bray RA, 2002. Diversity in the Monogenea and Digenea: does lifestyle matter? International Journal for Parasitology, 32: 321-328. 
[27] Madhavi R, 2001. Family Monorchiidae Odhner, 1911. In Keys to the Trematoda, vol: 3, Bray, R:A., Gibson, D.I. and Jones A. (Eds). CAB International, Wallingford, U.K. 145-175

[28] Jousson O, Bartoli P, 2002. Species diversity among the genus Monorchis (Digenea: Monorchiidae) parasitic in marine teleosts: molecular, morphological and morphometrical studies with a description Monorchis blennii n. sp. Parasitology Research, 88: 230-241.

[29] Korniychuk JM, 1997. Trematode fauna of four common blenniid species in the Black Sea. Ekologiya Morya, 46: 4346 (In Russian).

[30] Gibson DI, 2002. Family Derogenidae Nicoll, 1910. In: D. I. Gibson, A. Jones, and R. A. Bray (eds.) Keys to the Trematoda, Vol.1. Wallingford: CABI Publishing and The Natural History Museum, pp. 351-368
[31] Kostadinova A, Power AM, Fernandez M, Balbuena JA, Raga JA, Gibson DI, 2003. Three species of Magnibursatus Naidenova, 1969 (Digenea: Derogenidae) from Atlantic and Black Sea marine teleosts. Folia Parasitologica, 50: 202-210.

[32] Kostadinova A, Bartoli P, Gibson DI, Raga JA, 2004. Redescriptions of Magnibursatus blennii (Paggi \& Orechhia, 1975) n. comb. and Arnola microcirrus (Vlasenko, 1931) (Digenea: Derogenidae) from marine teleosts off Corsica. Systematic Parasitology, 58: 125-137.

[33] Kostadinova A, Gibson DI, 2009. New records of rare derogenids (Digenea: Hemiuroidea) from Mediterranean sparids, including the description of a new species of Magnibursatus Naidenova, 1969 and redescription of Derogenes adriaticus Nikolaeva, 1966. Syst Parasitol (2009) 74: 187-198. DOI 10.1007/s11230-009-9214-6 